\title{
Phytochemical Characterization and Antioxidant Bioactivity of Androgra- phis paniculata (Nees)
}

\author{
Abiodun O. Owoade ${ }^{1^{*}}$, Abdullahi O. Alausa ${ }^{1}$, Adewale Adetutu ${ }^{1}$, Olubukola S. \\ Olorunnisola ${ }^{1}$, Akinade W. Owoade ${ }^{2}$ \\ ${ }^{I}$ Department of Biochemistry, Faculty of Basic Medical Sciences, Ladoke Akintola University \\ of Technology, Ogbomoso, Nigeria. \\ ${ }^{2}$ Department of Biochemistry, Faculty of Basic Medical Sciences, College of Medicine, Univer- \\ sity of Ibadan, Ibadan, Nigeria
}

\begin{abstract}
*Correspondence should be addressed to Abiodun O. Owoade: aoowoade@lautech.edu.ng
Received 21st May 2021; Revised 13th July 2021; Accepted 14th July 2021

(C) 2021 Owoade et al. Licensee Pan African Journal of Life Sciences an official publication of Faculty of Basic Medical Sciences, Ladoke Akintola University of Technology, Ogbomoso. This is an Open Access article distributed under the terms of the Creative commons Attribution License (https://creativecommons.org/licenses/BY/4.0), which permits unrestricted use, distribution, and reproduction in any medium, provided the original work is properly cited.
\end{abstract}

\begin{abstract}
Background: Medicinal plants are natural sources of antioxidants effective in the treatment of radicalmediated diseases. This study evaluated the in-vitro antioxidant and phytochemical constituents of the methanolic leaves extract of Andrographis paniculata .
\end{abstract}

Methods: Fresh A. paniculata leaves were harvested from a local farm, air-dried and extracted with methanol. Chemical composition, antioxidant activities, and $\alpha$-amylase enzyme inhibitory potentials of the extract were determined

Results: The extract of $A$. paniculata concentration-dependently scavenges 2,2-Diphenyl-1-picrylhydrazyl (DPPH) and 2,2'azinobis (3-ethylbenzothiazoline-6-sulphonic acids) (ABTS) radicals. It scavenges nitric oxide radicals with IC50 of $145.99 \mu \mathrm{g} / \mathrm{ml}$ compared to $167.17 \mu \mathrm{g} / \mathrm{ml}$ of standard ascorbic acid and has $41 \%$ activity of standard ascorbic acid ferric reducing power. The extract also inhibited the induction of lipid peroxidation and $\alpha$ Amylase activity in a concentration-dependent manner. The phytochemical assays employed revealed the presence of various phytochemicals in the extract. Further analysis with gas-chromatography revealed the possible presence of Andrographolide, Deoxyandrographolide, Apigenin, Kaempferol, Quercetin, Methyl vanillate, Methyl Caffeate, Beta-sitosterol, Vanillic acid in the extract. The total phenolics content was found to be $29.11 \mathrm{mg} \mathrm{GAE} / \mathrm{g}$, and proximate analysis revealed the moisture content, crude protein, crude fat, crude fiber, total ash, and Nitrogen free extract to be $21.89 \%, 5.66 \%, 8.74 \%, 0.95 \%, 6.87 \%$, and $55.89 \%$ respectively.

Conclusion: The plant $A$. paniculata demonstrated good antioxidant potentials and contain various phytochemicals. Therefore, it could be inferred that the effectiveness of $A$. paniculata as a medicinal plant could be due to the presence of various phenolics and antioxidant compounds in the plant.

Keywords: Phytochemical constituents, Andrographis paniculata, Antioxidant, Lipid peroxidation, Gaschromatography 


\subsection{INTRODUCTION}

Plants are enriched with several phytochemical compounds such as tannins, coumarins, quinones, anthraquinone, amine, triterpenoids, lignans, flavonoids and many other secondary metabolites, which are a great source of reactive oxygen species scavengers $[1,2]$. They also contain antioxidant compounds and have been reported to have wound healing, anticancer, antimutagenic, anti-inflammatory and antihypertensive properties in many studies $[1,3]$. Consumption of a rich diet in natural antioxidants has been shown to decrease cardiovascular disease and reduce the risk of cancer, ageing-related disease among others [4].

Researchers globally in the last decade are working towards the employment of natural phytochemicals present in herbs, leafy vegetables, beans, berry, cherries and crops in the management of diseases [5]. Many secondary plant metabolites with limited research studies are being subjected to extensive investigation to determine their suitability as a pharmacological agent [1]. Andrographis paniculata also called the king of bitters is a traditional herbaceous plant of the family Acanthaceae. It is widely cultivated across Europe, Asia, Africa, and used to manage various ailments [6,7]. Several studies have demonstrated the anticancer, anti-inflammatory, hypotensive property, antiangiogenic, antihyperglycemic and antimalarial properties of $A$. paniculata extract [8$10]$.

Many bioactive compounds such as andrographolide, 14deoxy-11,12-didehydroandrographolide, kaempferol, quercetin, 14-deoxy andrographolide and many others have been isolated from A. paniculata [11]. The role of andrographolide (major bioactive compound of $A$. paniculata) was highlighted in a study to be (i) abatement of acute brain injury in Wistar rats [12], (ii) amelioration of permanent middle cerebral artery occlusion (pMCAO ), (iii) reduced neurological deficits in mice and (iv) good antiviral potency $[13,14]$. Therefore, this study aims to determine the phytochemical composition and antioxidant efficacy of A. paniculata methanolic extract in the quest to strengthen scientific knowledge.

\subsection{METHODOLOGY}

\subsection{Reagents}

Ferric chloride, dinitro salicylic acid reagent, butanol, 2,2 -Diphenyl-1-picrylhydrazyl (DPPH), ethanol, FolinCiocalteu reagent, starch, thiobarbituric acid, sodium carbonate, sodium chloride, sodium nitroprusside, naphthyl ethylenediamine dichloride, $\alpha$-amylase, glacial acetic acid and potassium hexacyanoferrate, and trichloroacetic acid were obtained from Sigma-Aldrich Chemical Co. Ltd. (England).

\subsection{Plant Materials and Extract Preparation}

A. paniculata leaves were obtained from a local farm at Ibadan, Oyo State. The identification and authentication of the plant were done at the Department of Pure and Applied Biology, Ladoke Akintola University of Technology, Ogbomoso by Prof A.J. Ogunkunle and a specimen was deposited in the herbarium with voucher number LH0538. The leaves were air-dried at room temperature and grounded into a powder. One hundred gram $(100 \mathrm{~g})$ of the powdered $A$. paniculata leaves were soaked in $500 \mathrm{ml}$ of methanol and shaken for 72 hours. Afterwards, it was filtered and the supernatant was concentrated and evaporated to dryness at $50^{\circ} \mathrm{C}$ with a rotary evaporator under reduced pressure.

\subsection{2,2-Diphenyl-1-picrylhydrazyl (DPPH) Radical Scavenging Activity}

The assay was performed as previously described by Schelesier et al., [15]. In the DPPH assay, the radical solution is prepared by dissolving $2.4 \mathrm{mg}$ DPPH in $100 \mathrm{mls}$ of ethanol. Antioxidants reduce the free radical 2,2-Diphenyl-1-picrylhydrazyl, which has an absorption maximum at $517 \mathrm{~nm} .1 .95 \mathrm{ml}$ DPPH was measured as blank, for the photometric assay, $1.95 \mathrm{ml}$ DPPH solution and $50 \mu$ antioxidant solution (plant extract or standard gallic acid) were mixed. The reaction was measured after 30 minutes until $\Delta \mathrm{A}=0.003 \mathrm{~min}-1$. The anti-oxidative activity was calculated using the following equation.

$\%$ Inhibition activity $=\frac{\mathrm{A}(\mathrm{DPPH})-\mathrm{A}(\mathrm{Extract})}{\mathrm{A}(\mathrm{DPPH})} \times 100$

Where $\mathrm{A}=$ Absorbance

\subsection{Trolox Equivalent Antioxidant Capacity Assay (ABTS)}

$1 \mathrm{ml}$ of freshly prepared ABTS solution and various concentrations of extract ranging from $20-100 \mu \mathrm{L}$ were mixed for 45 seconds and measured immediately after 1 minute at $734 \mathrm{~nm}$. The extract antioxidant activity was determined using the following equations; 
$\%$ Inhibition activity $=((\mathrm{A}(\mathrm{ABTS}+)-\mathrm{A}($ Extracts $)) /(\mathrm{A}$ (ABTS) X 100

\section{Where $\mathrm{A}=$ Absorbance}

\subsection{Ferric Reducing Antioxidant property (FRAP) Assay}

The Fe3+ reducing power of the extract was determined by the method of Oyaizu [16]. Various concentrations of extract at $0.75 \mathrm{~mL}$ was mixed with $0.75 \mathrm{~mL}$ of potassium hexacyanoferrate $[\mathrm{K} 3 \mathrm{Fe}(\mathrm{CN}) 6](1 \%, \mathrm{w} / \mathrm{v})$ and $0.75 \mathrm{~mL}$ of phosphate buffer $(0.2 \mathrm{M}, \mathrm{pH}$ 6.6). The mixture was incubated for $20 \mathrm{~min}$ at $50^{\circ} \mathrm{C}$ in a water bath. The $10 \%$ trichloroacetic acid (TCA) solution $0.75 \mathrm{~mL}$ was then added to stop the reaction, this was centrifuged for 10 min at $3000 \mathrm{r} / \mathrm{min}$. The supernatant $(1.5 \mathrm{~mL})$ was mixed with $0.1 \mathrm{~mL}$ of ferric chloride $\left(\mathrm{FeCl}_{3}\right)$ solution $(0.1 \%$, w/ v) and $1.5 \mathrm{~mL}$ of distilled water for $10 \mathrm{~min}$. The absorbance at $700 \mathrm{~nm}$ was measured as the reducing power, the higher the absorbance the greater is the reducing power.

\subsection{Nitric Oxide Scavenging Activity}

This was carried out using the method described by Garrat [17]. $2 \mathrm{ml}$ of $10 \mathrm{mM}$ sodium nitroprusside was dissolved in $0.5 \mathrm{ml}$ phosphate buffer of $\mathrm{PH} 7.4$. The dissolved mixture was mixed with $0.5 \mathrm{ml}$ of $A$. paniculata extract at ranging concentrations. The mixture was incubated at room temperature for two and a half hours. $0.5 \mathrm{ml}$ of incubated sample plus $0.5 \mathrm{ml}$ of Griess reagent were then re-incubated for thirty minutes and the absorbance was measured at $546 \mathrm{~nm}$. Percentage inhibition was calculated as;

Inhibition of NO radical $=[$ Ao $-A 1 /$ Ao X 100]

Where A0 is the absorbance before reaction and A1 is the absorbance after reaction has taken place with Griess reagent.

\subsection{Lipid Peroxidation Inhibition Assay}

This is a modified thiobarbituric acid reactive substance (TBARS) assay (18). The lipid source is egg yolk homogenate and Fenton Reagent $\left(\mathrm{FeSO}_{4} / \mathrm{H}_{2} \mathrm{O}_{2}\right)$ was the source of free radicals. The reaction mixture containing $0.5 \mathrm{ml}$ egg yolk homogenate $(10 \%$ in distilled water $\mathrm{V} / \mathrm{V})$, $0.05 \mathrm{ml} \mathrm{FeSO}_{4}(0.07 \mathrm{M})$, and $0.1 \mathrm{ml}$ of the extract was incubated for $30 \mathrm{~min}$. The absorbance was read at $532 \mathrm{~nm}$ and the percentage induction of lipid peroxidation is $100 \%$ in the control which is compared to the reduction in the plant extract samples.
Induction of lipid peroxidation $(\%)=100-[(\mathrm{A} 0-\mathrm{A} 1) /$ A $0 \times 100]$

Where Ao is the absorbance of the control and A1 is the absorbance of the sample

\subsection{Inhibition of Alpha-amylase}

The determination of $\alpha$-amylase inhibition was carried out using a modified dinitrosalicylic acid (DNS) method previously described by Bernfeld [19]. $1 \mathrm{~mL}$ of methanolic extracts of $A$. paniculata were pre-incubated with $\alpha$ amylase $1 \mathrm{U} / \mathrm{mL}$ for $30 \mathrm{~min}$. The starch solution $1 \mathrm{~mL}$ $(1 \% \mathrm{w} / \mathrm{v})$ was added to the mixture and incubated for 10 $\min$ at $37^{\circ} \mathrm{C}$. The $1 \mathrm{~mL}$ DNS reagent $(12.0 \mathrm{~g}$ of sodium potassium tartrate tetrahydrate in $8 \mathrm{~mL}$ of $2 \mathrm{M} \mathrm{NaOH}$ and

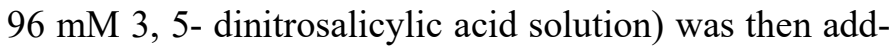
ed to the reaction to stop it. This was followed by heating in a boiling water bath for $5 \mathrm{~min}$. A control was prepared by using buffer $(20 \mathrm{mM}$ Sodium phosphate buffer with $6.7 \mathrm{mM}$ Sodium chloride, $\mathrm{pH} 6.9$ at 20oC) instead of plant extracts. The absorbance was read at $540 \mathrm{~nm}$.

$$
\% \text { inhibition }=[\text { Ao }- \text { A1 }] / \text { Ao } x 100
$$

Where Ao is the absorbance of the control and A1 is the absorbance of the sample

\subsection{Phytochemical Composition Screening}

Qualitative analysis of $S$. siamea methanolic extract was carried out by testing for the presence of flavonoids, terpenoids, tannins, phenols, saponins, phytosterol, alkaloids, phlobotannins and cardiac glycoside. Each assay was carried out following the method of Sofowora et al., [20] for flavonoids, Ejikeme et al., [21] for terpenoids and tannins, Santhi et al., [22] for phenol, Harbone et al., [23] for saponins, phytosterol and alkaloids, Ajiboye et al., [24], for phlobotaninns and cardiac glycoside

\subsection{Determination of total phenolic compound in methanolic extract of $\boldsymbol{A}$. paniculata}

Total phenolics of $A$. paniculata were determined by the Folin-Ciocalteu method (Folin Ciocalteu et al.,) [25]. For the preparation of the calibration curve, $1 \mathrm{ml}$ FolinCiocalteu reagent (diluted ten-fold) and $4 \mathrm{ml}(75 \mathrm{~g} / \mathrm{L})$ sodium carbonate were mixed with $1 \mathrm{ml}$ of aliquots of 0.24 , $0.075,0.0105$ and $0.3 \mathrm{mg} / \mathrm{ml}$ ethanol gallic acid solutions. The absorbance was read at $765 \mathrm{~nm}$ after 30 minutes and the calibration curve was drawn. $1 \mathrm{ml}$ Folin-Calteus reagent and $4 \mathrm{ml}(75 \mathrm{~g} / \mathrm{L})$ sodium carbonate was mixed with $1 \mathrm{ml}$ of $A$. paniculata and after 30 minutes the absorbance 
was read for the determination of plant phenolic. The total content of phenolic compounds in A. paniculata (Gallic acid equivalent) was calculated using the following formula

$\mathrm{C}=\mathrm{c} . \mathrm{v} / \mathrm{m}$

Where $\mathrm{C}$ is the total content of phenolic compound $(\mathrm{mg} / \mathrm{g}$ plant extract, in GAE)

$\mathrm{c}$ is the concentration of Gallic acid established from the calibration curve in $\mathrm{mg} / \mathrm{ml}$

$\mathrm{v}$ is the volume of extract in $\mathrm{ml}$

$m$ is the weight of pure plant extract.

\subsection{Gas Chromatography Analysis}

The gas chromatography (GC) study was done using Shimadzu GC-17A gas chromatography fitted with a Flame Ionization Detector (FID) and an autosampler. GC column used was, fused silica capillary column OV-1, DB-1 (30 $\mathrm{m} \times 0.53 \mathrm{~mm}, 0.5 \mu \mathrm{m}$ film thickness), at $75{ }^{\circ} \mathrm{C}$ and programmed to $75{ }^{\circ} \mathrm{C}$ at $240{ }^{\circ} \mathrm{C} / \mathrm{min}$ and 5 min hold. Injector and detector were at 240 and $250{ }^{\circ} \mathrm{C}$ respectively. About $1 \mu \mathrm{L}$ of each sample was injected, and the relative quantity of the chemical compounds present in the extract of $A$. paniculata was expressed as a percentage based on the peak area produced in the chromatogram. The identification of $A$. paniculata constituents was carried out by comparison of GC retention times of $A$. paniculata with $\mathrm{GC}$ retention times of desired standards compounds.

\subsection{Proximate Analysis of Andrographis paniculate leaves}

The roximate composition of $A$. paniculata leaf powder samples was determined using standard procedures. Moisture content was determined as described by Udo and Ogunwele [26] with slight modification. Ash was determined by incineration $\left(550^{\circ} \mathrm{C}\right)$ of known weights of samples in a muffle furnace [27]. The crude lipid content was determined using the Soxhlet method described by Udo and Ogunwele [26]. The Crude fiber was determined after digesting a known weight of fat-free sample with sulfuric acid and sodium hydroxide as described by Udo and Ogunwele [26]. The crude protein percentage was evaluated using the Miro-Kjeldahl method described by AOAC [28], while nitrogen-free extract (NFE) was determined by addition of all percent of moisture, fat, crude protein, ash and crude fiber subtracted from 100\% [29]

\subsection{Statistical Analysis}

Results are expressed as means \pm SEM. Statistical analyses were performed using one-way analysis of variance followed by Tukey's test. All analyses were done using Graph Pad Prism Software Version 5.00 and $\mathrm{p}<0.05$ was considered statistically significant.

\subsection{RESULTS}

\subsection{2,2-Diphenyl-1-picrylhydrazyl (DDPH) Radical Scavenging Activity}

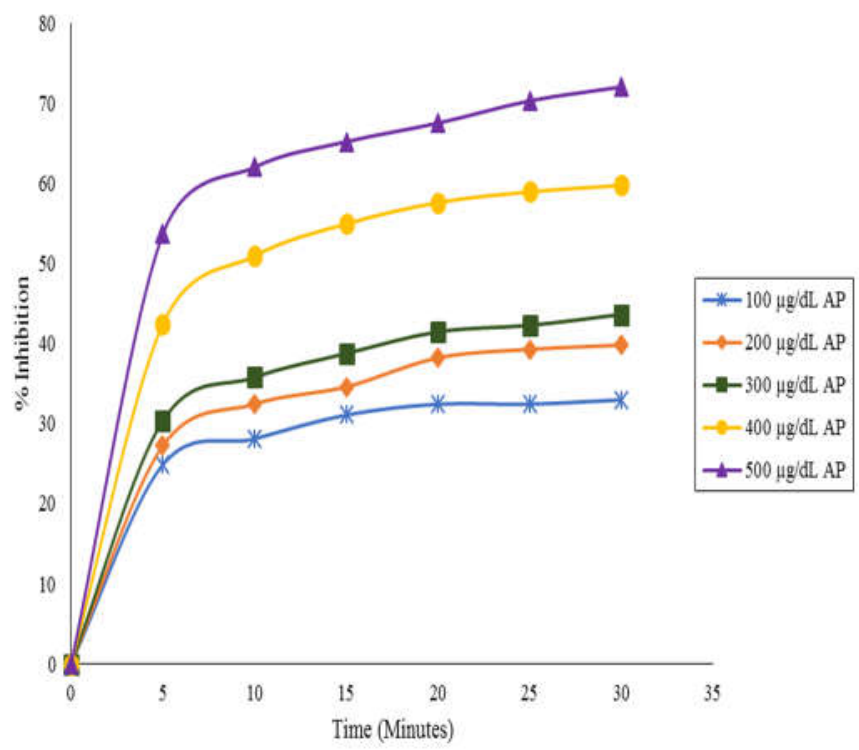

Figure 1. Effect of Time on Different Concentration of Methanolic extract of $A$. paniculata on Inhibition of DPPH Radical

The $A$. paniculata demonstrated a concentration and time -dependent scavenging activity by quenching DPPH radicals and was compared with gallic acid, as a positive control. The IC50 values (defined as the concentration of test compound required to produce $50 \%$ inhibition) obtained are $326.37 \mu \mathrm{g} / \mathrm{dL}$ and 16.13 and $\mu \mathrm{g} / \mathrm{dL}$ for $A$. $p a-$ niculata and gallic acid respectively (Figure 1 and 2)

\subsection{ABTS Radical Cation Scavenging Ability}

The scavenging abilities of $A$. paniculata leave against ABTS radicals were evaluated and compared with gallic acid. The scavenging capabilities were found to increase with the increasing concentration of $A$. paniculata and gallic acid. Comparatively, the scavenging abilities of $A$. paniculata were $25 \%$ of that of standard gallic acid at the same concentration and experimental conditions. 


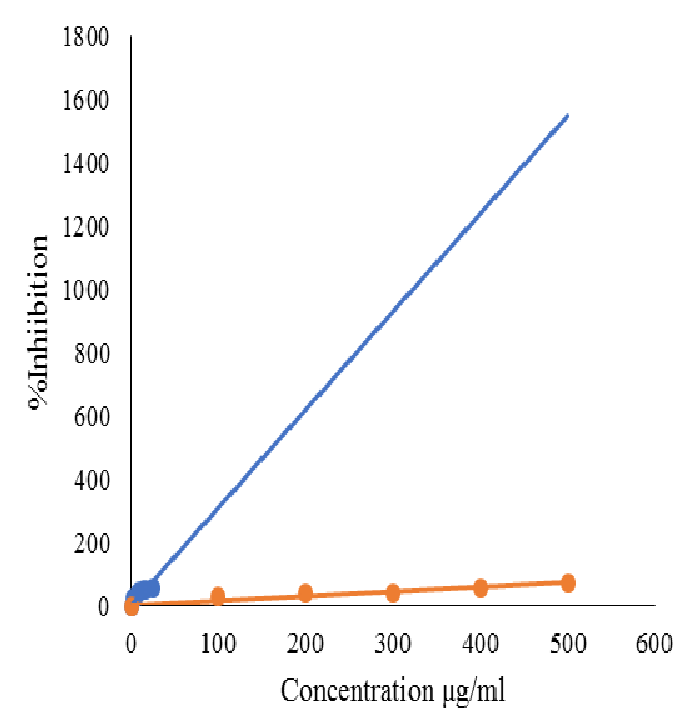

Figure 2. The Effects of Different Concentrations of A. Paniculata and Gallic on The Inhibition of the DPPH Radical.

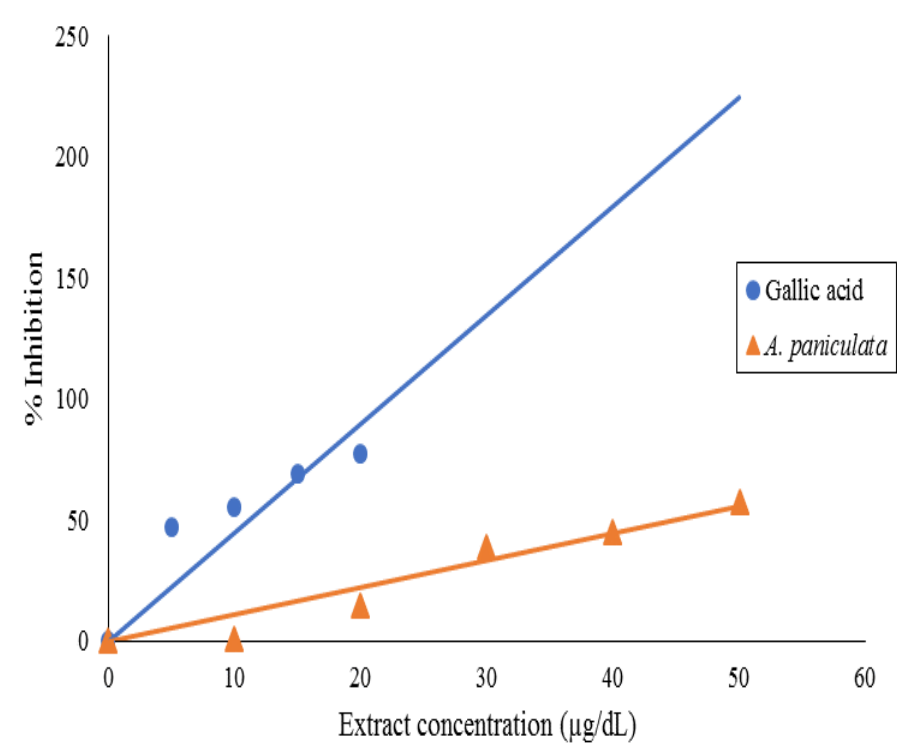

Figure 3. The Effects of Different Concentrations of $A$. panicula$t a$ and Gallic on the Inhibition of the ABTS Radical.

\subsection{Ferric Reducing Antioxidant Property (FRAP) Assay}

The reducing abilities of $A$. paniculata leaves were evaluated and compared with standard ascorbic acid. The reductive capabilities were found to increase with the increase in the concentration of standard ascorbic acid and $A$. paniculata. Comparatively, standard ascorbic acid has greater reducing power than $A$. paniculata with the reducing abilities of $A$. paniculata about $41 \%$ of that of standard ascorbic acid (Figure 4).

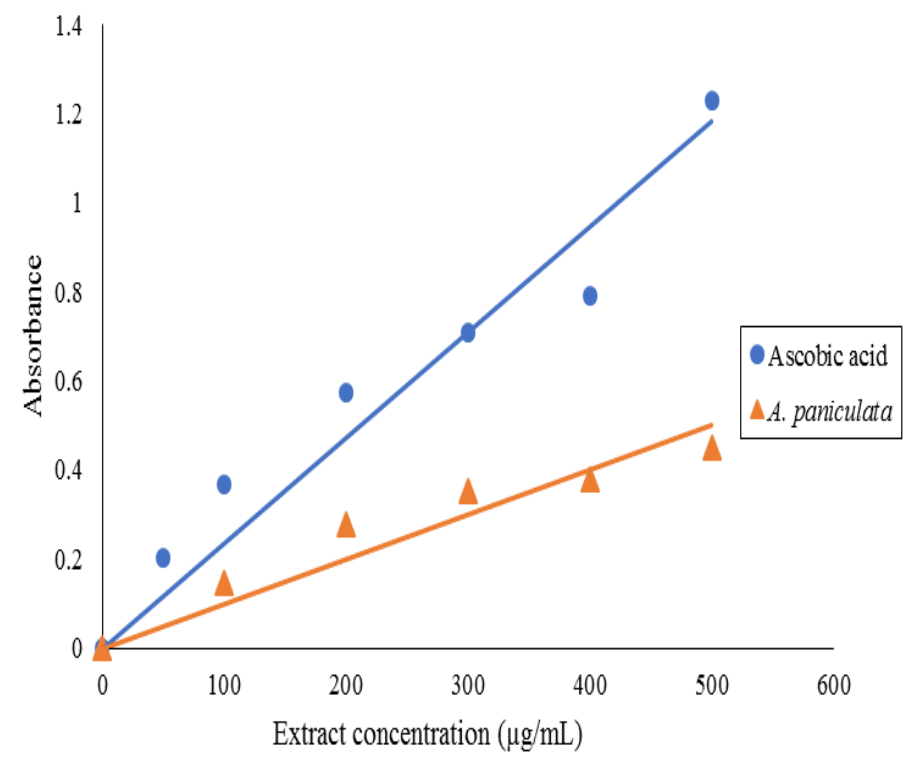

Figure 4. Ferric Reducing power of A paniculata and Ascorbic Acid at Different Concentrations

\subsection{Nitric Oxide Scavenging Activity}

The nitric oxide scavenging ability of $A$. paniculata extract and standard ascorbic acid was compared. The $A$. paniculata extract and standard ascorbic acid scavenge nitric oxide radicals in a concentration-dependent manner with IC50 values (known as the concentration needed to caused $50 \%$ inhibition) for $A$. paniculata and ascorbic acids given as $145.99 \mu \mathrm{g} / \mathrm{ml}$ and $167.17 \mu \mathrm{g} / \mathrm{ml}$ respectively (Figure 5).

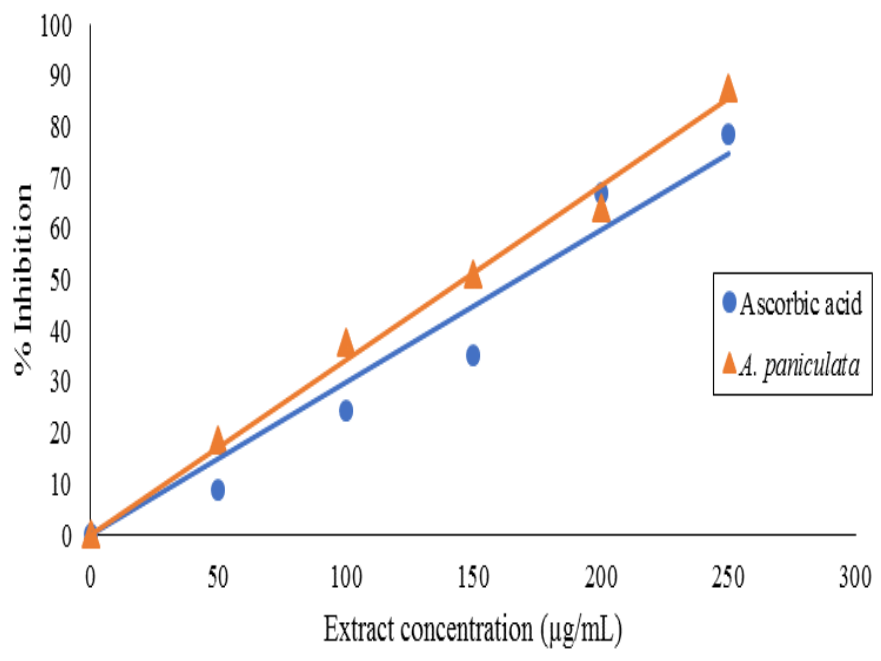

Figure 5. The eEfects of Different Concentrations of A. paniculata on the Inhibition of Nitric Oxide Radical Formation. 


\subsection{Lipid Peroxidation Inhibition Assay (TBARS)}

The ability of A. paniculata extract to inhibit the induction of lipid peroxidation was compared with the control sample which has $100 \%$ lipid peroxidation induction. The inhibition of lipid peroxidation induction by A. paniculata extract was found to be concentration-dependent with $100 \mu \mathrm{g} / \mathrm{mL}$ of the extract inhibited lipid peroxidation induction by $31.85 \%$ and $500 \mu \mathrm{g} / \mathrm{mL}$ of the extract inhibited lipid peroxidation induction by $74.48 \%$ (Figure 6 )

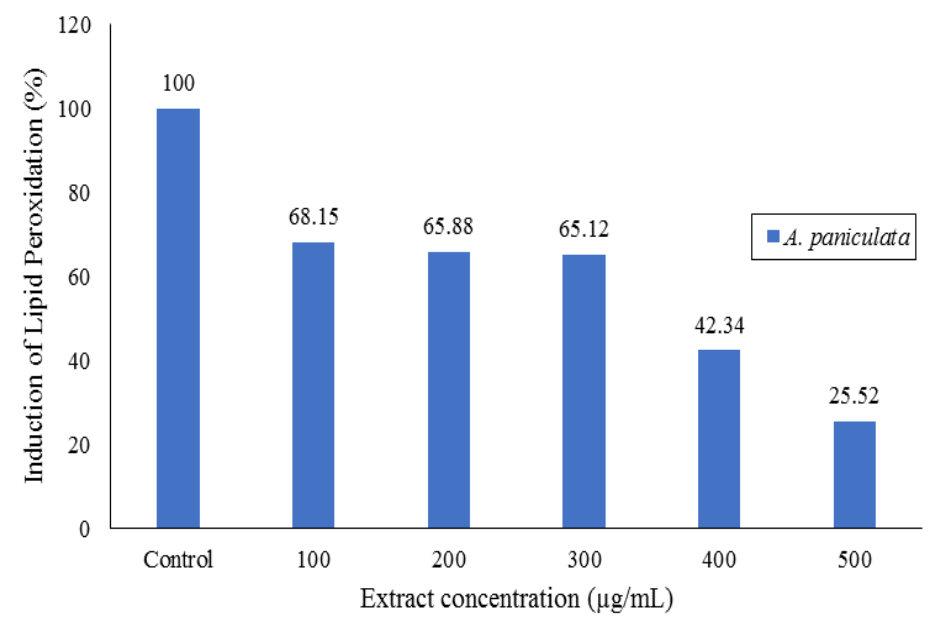

Figure 6. The Effects of Different Concentrations of $A$. paniculata on the Induction of Lipid Peroxidation

\subsection{Inhibition of $\alpha$ - Amylase}

The methanolic extract of $A$. paniculata significantly inhibited $\alpha$-amylase activity in this study. The level of inhibition was found to be concentration-dependent and the maximum percentage inhibition of $\alpha$-amylase activity of $81.82 \%$ was obtained at $250 \mu \mathrm{g} / \mathrm{dL}$ of the extract (Figure 7).

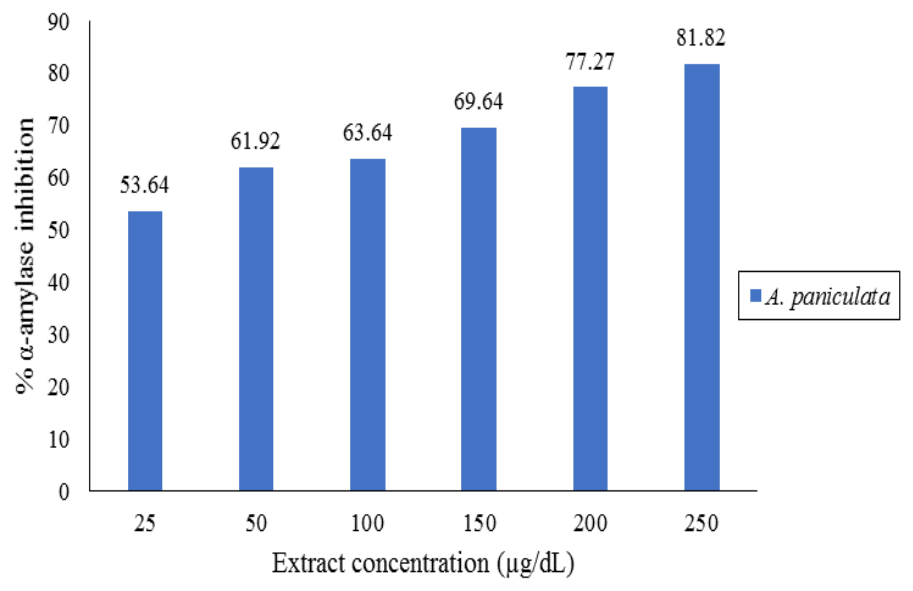

Figure 7. The Effects of Different Concentrations of $A$. paniculata on Inhibition of $\alpha$-amylase Activity.

\subsection{Qualitative Phytochemical Analysis of Powder Sample of $A$. paniculata}

The result of the qualitative analysis of the phytochemicals in A. paniculata extract is presented in Table 1 . The study revealed the presence of alkaloids, flavonoids, tannins, phenol, terpenoids, phlobotanins, cardiac glycosides, and saponin, in the A. paniculata extract while phytosterols was absent

Table 1: Phytochemical Composition of the Methanolic Leaves Extract of $A$. paniculata

\begin{tabular}{|c|c|c|c|}
\hline Constituents & Test & Observation & $\begin{array}{l}\text { Infer- } \\
\text { ence }\end{array}$ \\
\hline Terpenoid & $\begin{array}{l}\text { Chloroform } \\
\text { test }\end{array}$ & $\begin{array}{l}\text { Brown ring for- } \\
\text { mation }\end{array}$ & + \\
\hline Saponins & Foam test & $\begin{array}{l}\text { Foam for some } \\
\text { minute on the ad- } \\
\text { dition of olive oil }\end{array}$ & + \\
\hline Phenols & $\begin{array}{l}\text { Ferric } \\
\text { Chloride Test }\end{array}$ & Bluish Black & + \\
\hline Phlobotanins & $\begin{array}{l}\text { Hydrochloric } \\
\text { acid }\end{array}$ & $\begin{array}{l}\text { Deposit of red } \\
\text { precipitate }\end{array}$ & + \\
\hline Phytosterols & $\begin{array}{l}\text { Chloroform } \\
\text { test }\end{array}$ & $\begin{array}{l}\text { No brown ring } \\
\text { formation }\end{array}$ & - \\
\hline Alkaloids & Mayer's test & $\begin{array}{l}\text { Cream colour pre- } \\
\text { cipitate }\end{array}$ & + \\
\hline $\begin{array}{l}\text { Cardiac } \\
\text { glycosides }\end{array}$ & $\begin{array}{l}\text { Acetic acid } \\
\text { test }\end{array}$ & Violet-green ring & + \\
\hline Flavonoids & $\begin{array}{l}\text { Alkaline } \\
\text { reagent }\end{array}$ & $\begin{array}{l}\text { Yellow coloura- } \\
\text { tion formation }\end{array}$ & + \\
\hline Tannins & $\begin{array}{l}\text { Ferric chlo- } \\
\text { ride test }\end{array}$ & $\begin{array}{l}\text { Brownish green } \\
\text { colouration }\end{array}$ & + \\
\hline
\end{tabular}

\subsection{Determination of Total Phenolic Compounds and Proximate Analysis of $\boldsymbol{A}$. paniculata}

The proximate analysis result reveals the percentage composition of moisture, crude protein, crude fat, crude fiber, total ash content and nitrogen-free fat content of methanolic extract of $A$. paniculata to be $21.89,5.66,8.74$, $0.95,6.87,55.89$ respectively as shown in Table 2 below. The phenolic content of A. paniculata extract was also determined in this study. The total amount of phenolic compounds present in the methanolic extract of $A$. paniculata was $29.11 \mathrm{mg}$ in gallic acid equivalent (GAE) (Table 2).

\subsection{GC Analysis}

The compounds likely present in the methanolic extract of A. paniculata leaves are presented in Table 3. The elution order in a GC column was used for the characterization and identification of the compounds. The elution time and the amount of these compounds were also presented. 
Table 2: The phenolic content and proximate analysis of $A$. paniculata

\begin{tabular}{ll}
\hline Sample & A. paniculata \\
\hline Moisture & 21.89 \\
Crude protein \% (\%n x 6.25) & 5.66 \\
Crude fat \% & 8.74 \\
Crude fibre \% & 0.95 \\
Total ash \% & 6.78 \\
NFE \% & 55.89 \\
Total phenolic content & 29.11 \\
\hline
\end{tabular}

From the result obtained quercetin $(9.88 \%)$ is the most abundant compound possibly present in the methanolic extract of $A$. paniculata. Also presented is the GC chromatograms (Fig 8), which show the detected peaks and their retention time in the column that correspond to the compounds present in the extract.

\section{DISCUSSION}

The imbalance between free radical generating and scavenging systems ultimately leads to oxidative stress which can be regarded as a multifactorial disease causative agent, with several known diseases including but not limited to cardiovascular disorders, neurodegenerative tauopathies, mitochondrial dysfunction, diabetes
Table 3. Biologically Active Chemical Compounds Present in A.paniculata Leaves Extract

\begin{tabular}{lll}
\hline $\begin{array}{l}\text { Name of com- } \\
\text { pounds }\end{array}$ & Retention time (min) & $\begin{array}{l}\text { Relative } \\
\text { abundance } \\
(\%)\end{array}$ \\
\hline p-Hydroxybenzoate & 2.63 & 8.31 \\
Caffeic acid & 3.53 & 1.53 \\
Methylcaffeate & 4.20 & 1.83 \\
Onysilin & 4.68 & 2.93 \\
Vanillic acid & 5.13 & 1.53 \\
Methyl vanillate & 6.05 & 5.83 \\
Cinnamic acid & 6.58 & 7.70 \\
Apigenin & 7.30 & 5.93 \\
Beta-sitosterol & 7.76 & 6.46 \\
Quercetin & 8.41 & 9.88 \\
Deoxygrapholide & 9.13 & 7.20 \\
Andrographolide & 9.73 & 4.87 \\
Kaempferol & 10.13 & 5.83 \\
Kalmegin & 10.85 & 8.49 \\
Ferulic acid & 11.38 & 3.82 \\
Adipic acid & 12.05 & 6.71 \\
Cosmosilin & 12.05 & 8.84 \\
Tetracosylferul & 13.25 & 1.45 \\
Skullcapflavone & 13.66 & 0.84 \\
\hline
\end{tabular}

mellitus among others [30]. Plants are vastly known to contain several bodily essential phytochemicals and metabolites, having a great impact in not only ameliorating

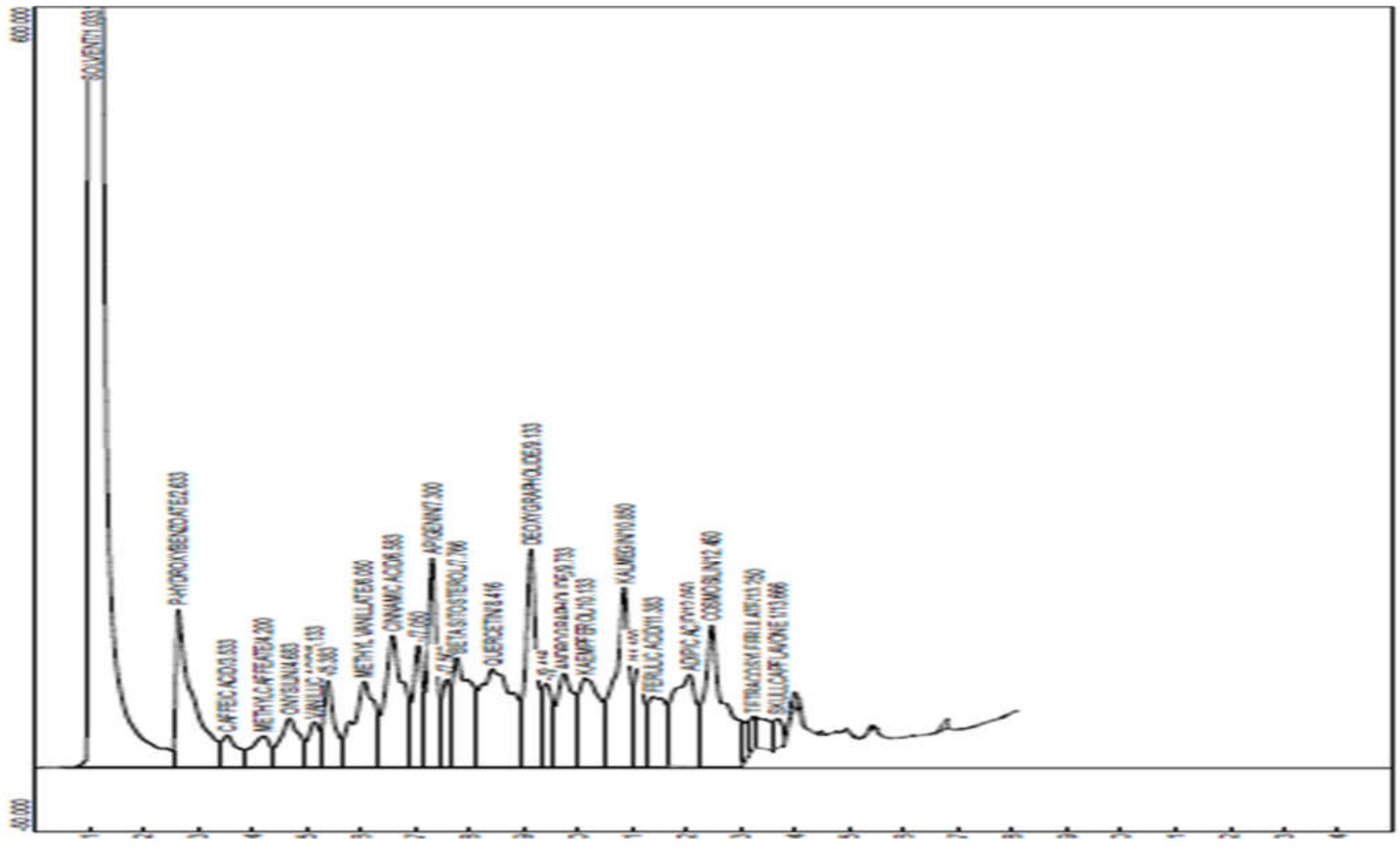

Figure 8. GC Chromatogram of A. paniculata Leaves Methanolic Extract. 
the derailing impact of oxidative stress but as well functioning as a defence system in protecting cells. Studies have, however explored several plants potentials, yielding a considerable amount of positive results $[31,32]$.

In evaluating the antioxidant status of medicinal plants, several biochemical cascades have come to prominence. These assays include DPPH, ABTS, lipid peroxidation, nitric oxide assay and ferric reducing power of such plants. This study, results revealed that A paniculata possess strong antioxidant scavenging potentials on DPPH and ABTS radicals in a concentration and timedependent manner. This result indicated that $A$. paniculata leaves extract has hydrogen donating ability, this agrees with previously reported study [33]. A similar antioxidant study (FRAP assay) evaluated in this study, A. paniculata showed great activity in reducing $\mathrm{Fe}^{3+}$ to $\mathrm{Fe}^{2+}$ in a highly reproducible and concentrationdependent manner. This thus indicates that $A$. paniculata has an embedded potential to transform free radicals into stable and unharmful products. This result is similar to a previous study carried out by Adedoyin et al., [34].

Under physiological condition, Nitric oxide radicals are generated and naturally reacts with oxygen to produce stable products. In this study, A. paniculata methanolic extract compared with the standard ascorbic acid demonstrated strong antioxidant potential against nitrite ion formation in a concentration-dependent manner. The nitric oxide radical scavenging activities of A. paniculata has been reported previously [35]. Lipid peroxidation/ malondialdehyde formation is generally believed to be a strong signal in free radicals impounded cells. This, however, triggers a cycle of toxicological cascades which if not put to check could disrupt biomembranes and wreak havoc [36]. Employing TBARS assay, maximum induction of MDA (100\%) was observed in the control while A. paniculata methanolic extract in a concentrationdependent manner successfully prevented MDA formation. Similarly, Bajpai et al., [35] reported the protective effects of $A$. paniculata against $\mathrm{Fe}^{3+}$-induced lipid peroxidation.

As earlier pointed, oxidative stress triggers the onset of diabetes mellitus. However, inhibitors of $\alpha$-amylase; a hydrolyzing enzyme, have been revealed as a hypoglycemic drug for the control of excessive blood glucose levels in humans [36]. The Cell-free antidiabetic assay carried out in this study showed that $A$. paniculata is effec- tive in inhibiting $\alpha$-amylase activity which might be attributed to the presence of phenolic compounds in the plant extract [38].

Plants have pharmacological activities attributed to the secondary metabolites which are responsible for essential bioactivities. Screening of the leaves of methanolic extract of $A$. paniculata revealed terpenoid, saponins, phenols, Phlobatanins, alkaloids, cardiac glycoside and flavonoid. These phytoconstituents have been reported to be associated with several nutritional bioactivities. Phytochemical composition screening of $A$. paniculata leaves shows the presence of saponins, which are triterpenoid glycosides responsible for the bitter taste and as well known for their hemolytic effect on red blood cells [39]. They possess cholesterol-reducing abilities and exhibit structure-dependent bioactivities [40]. The saponins content of plants also helps in fighting pathogens and boosting the immune system.

The presence of terpenoids indicates that steroidal compounds could be present, which are of great use/ importance in synthesizing sex hormones synthetic compounds [41]. Phlobatanins as well are researched for their analgesics and wound healing capabilities [41]. Flavonoids and phenols are responsible alongside carotene for the colouration of vegetables and herbs. They possess health-promoting benefits not limited to their antioxidant, anti-inflammatory and vaso-protective abilities. They act as diuretics and could possess anti-plasmodial properties. Thus, potentially making $A$. paniculata leaves a great medicinal herb to large varieties of diseases [42].

Alkaloids is present in several medicinal plants, and it constitutes an appreciable percentage in many available drugs, hence highly essential in diseases management. Moreso, cardiac glycosides possess an effective and direct action on the cardiac system, supporting the strength of the heart and the rate of contraction when failing [43].

The total phenolic content in methanolic leaves extract of A. paniculata determined in this study was found to be high. Therefore, it was considered that the high antioxidant potential of leaves extract of $A$. paniculata could be attributable to its high amount of phenolic compounds content. The nature of phenolic compounds present in A. paniculata extract was carried out using gas chromatography. GC analysis revealed hydroxybenzoate, caffeic acid, Methylcaffeate, onysillins, vannilic acid, methyl vanillate, cinnamic acid, apigenin, beta-sitosterol, quer- 
cetin, andrographolide, deoxy andrographolide, kaempferol, kalmegin, ferulic acid, adipic acid, cosmosilins, tertacosylferyl and skulcapflavon in the extract. Many of these compounds have been identified in A. paniculata in the previous study [11].

Proximate analysis of $A$. paniculata leaves revealed that the plant has a substantial amount of moisture, crude protein, crude fat, crude fibre, total ash content, and nitrogen-free extract. From the result, nitrogen-free fat has the highest value, while crude fibre has the smallest value. The ash content of $A$. paniculata leaves shows that the plant is rich in the mineral element, while the moisture content of the leaves would prevent microbial growth and increase the storage span [44]. The crude fibre in A. paniculata has the potential to reduce serum cholesterol levels, preventing coronary heart diseases, lowering constipation, and reduce the risk of hypertension [45]. Thus, the result obtained in this study offers a scientific basis that methanolic leaves extract from $A$. paniculata contains certain nutritional values that could be significant in managing malnutrition and multifactorial disorders.

The results obtained in this study indicate that $A$. paniculata extract, through its actions has good antioxidant properties. The bioactive compounds present in $A$. paniculata methanolic extract (majorly andrographolide, 14-deoxy-11,12-didehydroandrographolide and 14deoxy andrographolide) have been mentioned in previous studies to prevent the toxicity cascade usually triggered by radicals [46-48]. The anticancer, hepatoprotective activity, hypotensive property, antiangiogenic, antihyperglycemic and antimalarial potentials of $A$. paniculata have been reported in previous studies which can be attributed to the diverse group of phytochemicals such as diterpenoids, diterpene glycosides, lactones, flavonoids and flavonoids glycosides present in $A$. paniculata leaves $[49,50]$. In the present study, A. paniculata was shown to have an antioxidant effect. This could be attributed to the presence of phenols, terpenoids, cardiac glycoside, tannins, flavonoids and saponins found in the plant extract in this study. Also, flavonoids and terpenoids, in particular, have been speculated to be responsible for great antioxidant and anti-inflammatory potentials of $A$. paniculata in the previous study [51], and these constituents may account for good pharmacological properties of $A$. paniculata extract obtained in this study.
This study concludes that the phytochemical composition and proximate analysis of compounds naturally present in $A$. paniculata leaves possess fat and proteins, with an appreciable quantity of phytochemicals like alkaloids, phenols, and flavonoids that provide essential nutritional supplements in food and enhances bodybuilding. In addition, $A$. paniculata methanolic extract demonstrated strong antioxidant and antidiabetic properties which could be attributed to the various phytochemicals present in the extract.

\section{Conflict of Interest}

Authors declare that there is no conflict of interest.

\section{Funding}

This research was self-funded by the authors

\section{Authors' Contribution}

AOO conceived and designed the study, collected data, performed data analysis and contributed to manuscript writing. AOA contributed to data collected, data analysis tools and manuscript writing. AA contributed to study design and data analysis. OSO, AWO contributed to data analysis tools and analysis of data. All authors approved the final version of the manuscript

\section{References}

1. Gracelin DH, Britto AJ, Kumar BJR. Qualitative and quantitative analysis of Phytochemicals in five Pteris species. International Journal of Pharmacy and Pharmaceutical Sciences 2012; 5: 105-7.

2. Cai YZ, Sun M, Corke, H. Antioxidant activity of betalains from plants of the Amaranthaceae. J Agric Food Chem 2003; 51(8): 2288-94.

3. Zheng W, Wang SY. Antioxidant activity and phenolic compounds in selected herbs. J Agric Food Chem 2001; 49(11): 5165-70.

4 Sala A, Recio MD, Giner RM, Manez S, Tournier H, Schinella G, Rios JL. Antiinflammatory and antioxidant properties of Helichrysum italicum. J Pharm Pharmacol 2002; 54(3): 365-71

5 Ashokkumar D, Mazumder UK, Gupta M, Senthilkumar GP, Selvan VT. Evaluation of Antioxidant and Free Radical Scavenging Activities of Oxystelma esculentum in various in vitro Models. J Comp Integ Med 2008; 5(1): 16.

6 Kumar G, Singh D, Ahmed J, Tali D, Dheer D, Shankar R. Andrographolide: Chemicalmodification and its effect on biological activities. Bioorganic Chemistry 2020; 
95:103511

7 Jiashu L, Yaoying M, Jingjing W, Huaxing H, Xiaohua W, Zhuo C, Jinliang C, Haiyan H, Chao H. A review for the neuroprotective effects of andrographolide in the central nervous system. Biomedicine and Pharmacotherapy 2019; 117: 109078.

8 Kumar RA, Sridevi K, Vijaya Kumar N, Nanduri S, Rajagopal S. Anticancer and immunostimulatory compounds from Andrographis paniculata. J Ethnopharmacol 2004; 92: 291-5.

9 Sheeja K, Guruvayoorappan C, Kuttan G. Antiangiogenic activity of Andrographis paniculata extract and andrographolide. Int Immunopharmacology 2007; 7: 211-21.

10 Zhang XF, Tan BK. Antihyperglycemic and antioxidant properties of Andrographis paniculata in normal and diabetic rats. Clin Exp Physiol Pharmacol 2000; 27: 358-63.

11 Subramanian R., Asmawi ZM., Sadikun A. In vitro $\alpha$ glucosidase and $\alpha$-amylase enzyme inhibitory effects of Andrographis paniculata extract and andrographolide. Acta biochimica polonica 2008; 55(2): 391-8.

12 Tao L, Zhang L, Gao R, Jiang F, Cao J, Liu H. Andrographolide alleviates acute brain injury in a rat model of traumatic brain injury: possible involvement of inflammatory signaling, Front. Neurosci 2018; 12: 657.

13 Flores JJ, Zhang Y, Klebe DW, Lekic T, Fu W, Zhang JH. Small molecule inhibitors in the treatment of cerebral ischemia, Expert Opin, Pharmacother 2014; 15: 659-80.

14 Daneman R, Prat A. The blood-brain barrier. Cold spring Harbor Perspective in Biology 2015; 7: a020412.

15 Schlesier K, Harwat M, Böhm V, Bitsch R. Assessment of antioxidant activity by using different in vitro methods. Free Radical Research 2002; 36(2):177-87.

16 Oyaizu M. Studies on product of browning reaction prepared from glucose amine, Japan Journal Nutrition 1986; 44:307-15.

17 Garrat DC. The Quantitative analysis of Drugs. Chapman and Hall Ltd., Japan 1964; 3: 456-8

18 Janero DR. "Malondialdehyde and thiobarbituric acidreactivity as diagnostic indices of lipid peroxidation and peroxidative tissue injury," Free Radical Biology \& Medicine 1990; 9(6): 515-40

19 Bernfeld P. Amylases, Alpha and Beta. Vol. 1, Academic Press, 1955. p. 149.

20 Sofowara A. Medicinal Plants and Traditional Medicine in Africa. Spectrum Books, Ibadan Nigeria, 1993. P. 289.

21 Ejikeme CM, Ezeonu CS, Eboatu AN. "Determination of physical and phytochemical constituents of some tropical timbers indigenous to Niger Delta Area of Nigeria," European Scientific Journal 2014; 10(18): 247270.

22 Santhi K, Sengottuvel R. Qualitative and quantitative phy- tochemical analysis of Moringa concanensis Nimmo. Int. J. Curr. Microbiol. App. Sci 2016; 5(1): 633-640.

23 Harborne JB. Phytochemical methods. London: Chapman and Hall, Ltd 1973; p. 49-188.

24 Ajiboye BO, Ibukun EO, Edobor G, Ojo AO, Onikanni, SA. Int. J. Inv. Pharm. Sci 2013; 1(5): 428-32

25 Folin O, Ciocalteu V. (1927): Tyrosine and tryptophan determination in proteins. J, Biol. Chem 1927; 73: 627650

26 Udo EJ, Oguwele JA. Laboratory manual for the analysis of soil, plants and water samples. 3rd ed. Department of crop production, University of Ilorin, Kwara State Nigeria 1986; p. $131-52$.

27 James CS. Analytical chemistry of food. Chapman and Hall, London 1995; pp. $64-5$.

28 AOAC. Official Methods of Analysis. 14th ed. Association of Official Analytical Chemists 1990; Washington DC

29 Isong, E., Idiong. Nutrient content of the edible leaves of seven wild plants from Nigerian. Plant foods for human nutrition 1997; 51: 79-84

30 Owoade AO, Adetutu A, Olorunnisola OS, Ayinde KS. The in-Vitro Antioxidant Properties and Phytochemical Constituents of Citrullus Colocynthis Methanolic Extract. Elixir Appl. Botany 2018; 121: 51556-62.

31 Al-Snafi AE. Therapeutic properties of medicinal plants: a review of plants with antioxidant activity (part 1). International Journal of Pharmacology and Toxicology 2015; (3): 159-82.

32 Wang SY, Jiao H. Correlation of antioxidant capacities to oxygen radical scavenging enzyme activities in blackberry. J Agric Food Chem 2000; 48: 5672-6.

33 Krithika R., Verma R.J., Shrivastav PS. Antioxidative and cytoprotective effects of andrographolide against CCl4induced hepatotoxicity in HepG2 cells. Hum. Exp. Toxicol. 2013; 32: 530-543.

34 Adedoyin B, Muhammad A, Dangoggo SM, Rabah A, Sharples G, Nahar L, Sarker S. Chemical Composition and Bioactivity of the Essential Oil of Cassia singueana Flowers Growing in Nigeria Pharm Biomed Res 2019; 5(3):1-7.

35 Bajpai VK, Agrawal P, Park Y. Phytochemicals, antioxidant and anti-lipid peroxidation activities of Ethanolic extract of a medicinal plant, Andrographis paniculata. Journal of food Biochemistry 2014; 1-8

36 Coppen IN, Allen JC, Hamilton RJ. Rancidity in foods. Applied Science Publishers 1983; New York, USA.

37 Bailey CJ. New Approaches to the Pharmacotherapy of Diabetes, Vol. 2, 3rd Edition, Blackwell Science Ltd., UK 2003; p. 73.1-21.

38 Hanamura T, Hagiwara T, Kawagishi H. Structural and functional characterization of polyphenols isolated from 
acerola (Malpighia emarginata DC.) fruit. Biosci Biotechnol Biochem 2005; 69:280-6.

39 Prohp TP, Onoagbe IO. Determination of phytochemical composition of the stem bark of triplochiton scleroxylon k. schum. (sterculiaceae). International Journal of Applied Biology and Pharmaceutical Technology 2012; 3 (2): 68-76.

40 Roa RR, Babu RM, Rao MRV. Saponins as anticarcinogens. The J. Nutr 1995; 125: 717-24.

41 Okwu DE. Evaluation of the chemical composition of indigenous spices and flavouring Agents. Global J. Pure Appl. Sci 2001; 7(3): 455-9.

42 Trease GE, Evans WC. Phytochemicals. In: Pharmacognosy. 15th ed. Saunders Publishers, London 2002; p. 424, 221-9, 246-9, 304-6,331-2, 391-3.

43 Iwu MM. Hypoglycemic properties of Bridelia furruginear leaves. Fitoterapia 1983; 54: 243 -248.

44 Adeyeye EJ, Ayejuyo OO. Chemical composition of Cola acuminates and Garcina kola seed grown in Nigeria. International Journal of Food Science and Nutrition 1994; 45: 223-33.

45 Ishida H, Suzuno H, Sugiyama N, Innami S, Todokoro T, Maekawa A. Nutritional evaluationof chemical component of leaves and stems of sweet potatoes
(Euphorbiaceae). African Journal of Biochemistry 2000; 6(24): 2752-7

46 Afsane B, Thozhukat S, Seyed AM, Amirhossein S. Counteracting arsenic toxicity: Curcumin to the rescue? Journal of Hazardous Materials 2020; 400: 123160.

47 Kapahi P, Takahashi T, Natoli G, Adams SR, Chen Y, Tsien RY, Karin M. Inhibition of NF- $\kappa B$ activation by arsenite through reaction with a critical cysteine in the activation loop of IкB kinase. J. Biol. Chem 2000; 275: 36062-6.

48 Kumagai Y, Sumi D. Arsenic: signal transduction, transcription factor, and biotransformation involved in cellular response and toxicity. Annu. Rev. Pharmacol. Toxicol 2007; 47: 243-62.

49 Rao YK, Vimalamma G, Rao CV, Tzeng YM. Flavonoids and andrographolides from Andrographis paniculata. Phytochemistry 2004; 65: 2317-21.

50 Pholphana N, Rangkadilok N, Thongnest S, Ruchirawat $\mathrm{S}$, Ruchirawat M. Determination and variation of three active diterpenoids in Andrographis paniculata (Burm. f.) Nees, J. Satayavivad, Phytochem. Anal 2004; 15: 365-71.

51 Ghorbanpour M, Varma A. Medicinal Plants and Environmental Challenges. Springer International Publishing 2017. 